\title{
A Global Approach to Local Problems? How to Write a Longer, Deeper, and Wider History of the International Year of Disabled Persons in Kenya
}

\author{
Sam de Schutter \\ Leiden University \\ s.de.schutter@hum.leidenuniv.nl
}

\begin{abstract}
This article argues that writing longer, deeper and wider histories of UN observances can help to push forward the historiography of international organizations, and to overcome global-local dichotomies in writing about international interventions in the Global South. To make this point, it uses one historical case study: the International Year of Disabled Persons (IYDP) in 1981 and how it played out in Kenya. The main argument is that this UN observance did not bring about "global" approaches that stood in stark contrast to "local" ways of dealing with disability. Writing a longer history shows how the approaches promoted during the IYDP can be traced back to late colonialism; a deeper history shows how this event played out on the ground, rather than on an abstract global level; and a wider history lays bare the broad range of actors involved beyond "the UN."
\end{abstract}

\section{Keywords}

Kenya - International Year of Disabled Persons - ILO - disability - colonialism international organizations - development.

\section{Introduction ${ }^{1}$}

In 1999, the Organization of African Unity (OAU) proclaimed the African Decade of Persons with Disabilities (1999-2009). They did so because of a general

1 The author acknowledges the support of the ERC Consolidator Grant Rethinking Disability under grant agreement number 648115 . 
disappointment with the results of the earlier International Decade of Disabled Persons, which had been observed by the United Nations from 1983 to 1992. The Continental Plan of Action drafted for the African Decade in 2002 stated that the successes of the UN Decade, which had followed the UN International Year of Disabled Persons or IYDP (1981), were "more pronounced in the northern hemisphere than elsewhere." Besides a general lack of funding and publicity, they ascribed the lack of success in the Global South to the fact that "the UN Decade was, by and large, a global approach to the problems of disability and the solutions that were offered were general and global..."2 The reason why the OAU Assembly of Heads of State and Government declared an African Decade in 1999 was thus to provide a "local approach to the problems of disability" and to develop "local solutions to the problems."

This framing of the International Decade of Disabled Persons as being too "global" and the consequent search for "local" solutions is interesting. These remarks are a starting point for this article, which will attempt a historical analysis of these kinds of international observances from the perspective of the Global South in terms of their globality or locality. While it might make sense for the OAU to attack these UN initiatives as being too global in a political move to reclaim and 'Africanize' disability policies, it argues that as historians we must be cautious not to reproduce these kinds of global-local dichotomies. This article therefore focuses on the question of how to analyse historically the nature of international observances, and especially how these played out in the Global South. What does it mean for historians to write about "global" or "local" approaches? What is the value of these concepts in a historical analysis?

The article deals with these questions by approaching the International Year of Disabled Persons in 1981 through the lens of one national case study. It first briefly looks at how the IYDP played out in Kenya. The remainder of the article will then be devoted to tracing the longer historical roots of what happened in 1981. This sort of contextualization will help to put this UN observance into a more grounded and longer perspective. In looking at the longer history of what happened during the IYDP in Kenya, it traces the events back to the Second World War and the period of colonial rule. In terms of actors, it highlights the

2 African Union. Continental Plan of Action for the African Decade of Persons with Disabilities (1999-2009) (Addis Ababa: African Union, 2002), 5.

3 African Union, 5 . 
roles of both national and transnational actors. Within the latter group, specific attention is paid to the International Labour Organization (ILO), an organization that has been instrumental in the history of Kenya's disability policies. In the end, the aim of this article is to show how global-local dichotomies do not aptly capture the nature of UN observances like the IYDP, or by extension any intervention by international organizations in the Global South. The perspective offered in this article rather illustrates how the IYDP was a transnationally entangled event, grounded in a national context and in a much longer history that is neither global nor local, but intrinsically transnational.

The perspective on UN observances proposed in this paper conforms to some recent trends in historiography and also draws some inspiration from anthropology. Since a considerable part of this paper focuses on the ILO - which, according to Daniel Maul, "became an international development agency" after 1948 - it draws extensively on the historiography of development. ${ }^{4}$ Joseph Hodge argues that a "new wave" of development historiography, since roughly the last decade, provides (or at least promises) longer, deeper and wider histories. Although the subject of this article might not be what Hodge had in mind, it does follow his proposed trifold approach. It provides a longer history, tracing the events in the 1980 s back to their colonial roots; a deeper history, centred on "actually existing" development and looking at "what's happening on the ground;" and a wider history, taking into account transnational connections and international organizations. ${ }^{5}$ The combination of these approaches shifts the focus to how a UN observance, and interventions by UN agencies in general, actually worked, not on an abstract, discursive level, but in concrete and lived projects, policies and programmes.

In that respect, anthropologists of development have offered some useful insights, moving away from a view of development as policy-driven towards analyses of development as a negotiated practice. As Tania Murray Li suggests in The Will to Improve:

An explicit, calculated program of interventions is not invented ab initio. ... Although there are occasions when a revolutionary movement or visionary announces a grand plan for the total transformation of

4 Maul, D. "Help Them Move the ILo Way: The International Labor Organization and the Modernization Discourse in the Era of Decolonization and the Cold War." Diplomatic History 33 (3) (2009), 390 .

5 Hodge, J.M. "Writing the History of Development (Part 2: Longer, Deeper, Wider)." Humanity 7 (1) (2016), 125 . 
society ... more often programs of intervention are pulled together from an existing repertoire, a matter of habit, accretion, and bricolage. ${ }^{6}$

David Mosse takes it even one step further and asks: what if development practice is not driven by policy? In his book Cultivating Development, Mosse aims to "reinstate the complex agency of actors in development at every level." He tries to understand how development is a negotiated practice, shifting the focus from policy to the "social life of projects, organisations and professionals." Applying these insights to a historical study of the IYDP forces us to turn our attention away from the "grand plans" and towards the "social life" of such an observance and what happened on the ground in a country like Kenya, taking into account the agency of all the different actors and organizations involved. This also coincides with new ideas about writing histories of international organizations like the UN or the ILO. Sandrine Kott, for example, has argued for a "heuristic displacement," shifting the focus away from "large plenary meetings" to "the work of the secretariats, commissions, and technical agencies." It is there that the "process-driven, often conflict-ridden nature" of international organizations becomes visible. ${ }^{8}$ One good example of an attempt to put this insight into practice is the edited volume by Poul Duedahl, $A$ History of UNESCO, in which the authors explicitly shift the focus from writing intellectual histories of the organization - or what Duedahl calls the roots of UNESCO initiatives - towards writing "historical impact studies," i.e. how the organization's initiatives had an impact on the ground. ${ }^{9}$

Lastly, as Hodge points out in his two-part essay, writing longer histories of development is not entirely new. The idea that the roots of the development concept in Africa (or elsewhere) can be traced back to the (late) colonial period is widely accepted. In the same way, many researchers have observed the continuities between the colonial and the postcolonial period, be it in ideas, institutions or personnel. This observation has led some to criticize the idea of development as "colonialism by other means," but historians have generally

6 Li, T.M. The Will to Improve: Governmentality, Development, and the Practice of Politics (Durham: Duke University Press, 2007), 6.

7 Mosse, D. Cultivating Development: An Ethnography of Aid Policy and Practice (London: Pluto Press, 2005), 6.

8 Kott, S. "International Organizations - A Field of Research for a Global History." Zeithistorische Forschungen/Studies in Contemporary History 8 (3) (2011), 447.

9 Duedahl, P. "Out of the House: On the Global History of Unesco, 1945-2015." In A History of UNESCO: Global Actions and Impact, ed. P. Duedahl (Basingstoke: Palgrave Macmillan, 2016), 4,7 . 
taken this as a starting point to write more nuanced and complicated histories. ${ }^{10}$ Hodge himself is one of the main proponents of this strand in the historiography on development in Africa. In Triumph of the Experts he analyses how, propelled by scientific and technical experts, development emerged as a central doctrine in the late colonial period, but he also aims "to piece together the intellectual and administrative legacies it left behind."11 Be it "the heavy bias in favor of state-centered ideologies and development structures," "the depoliticization of poverty and power achieved by recasting social and economic problems as technical ones that could be fixed by rational planning and expert knowledge" or "ideas and ideological assumptions" more generally, the lasting effects of late colonial interventions were tangible far beyond the moment of independence..$^{12}$ In that regard Kenya is no exception to the rule that "contemporary development practice has its roots in the colonial period," as there too, according to Joanna Lewis, changes in colonial welfare and development policies after the Second World War "set the pattern for much of twentieth-century development practice in clear-cut and often negative ways." ${ }^{\text {13 }}$

The remainder of this article is divided into three main parts. In the first section it provides a brief overview of how the IYDP played out in Kenya. It gives an idea of what happened in the run-up to and during this UN observance, and what kinds of approaches were promoted at that time. In the second part it traces the longer history of these approaches. Going back to the 1940s, it shows when, how and why these concepts were introduced in Kenya and how over time they became entrenched into the fabric of social policies in the country. In the last section it returns to the 1980 s in an attempt to bring everything together and answer the question of how to go about historically analysing an international observance like the IYDP.

On the $25^{\text {th }}$ of November 1976, the Social and Humanitarian Committee of the United Nations unanimously adopted a resolution proclaiming the year 1981 as

\footnotetext{
10 Cooper, F. “Writing the History of Development." Journal of Modern European History 8 (1) (2010), 8 .

11 Hodge, J.M. Triumph of the Expert: Agrarian Doctrines of Development and the Legacies of British Colonialism (Athens: Ohio University Press, 2007), 20.

12 Hodge, J.M. Triumph, 19.

13 Lewis, J. Empire State-Building: War \& Welfare in Kenya, 1925-52 (Oxford: James Currey, 2000), 2-3.
} 
the International Year for Disabled Persons (IYDP). ${ }^{14}$ The initiative for this proposal came from the Libyan Arab Republic, but the majority of member states supported and co-sponsored it, including Kenya. The day after the session, the Kenyan representative wrote to the Minister of Foreign Affairs, stating that he could not "over-emphasize the sentiments which were expressed by most delegations in support of the year."15 Immediately, it seemed as if there was a great sense of urgency to heed the call of the International Year to take measures and implement programmes for the benefit of people with disabilities. In February 1977, the Commissioner of Social Services was urged to "act now before it is too late," and two weeks later he was again reminded that time was "running out."16 By May 1977, the commissioner was busy collecting reports from the relevant ministries (education, health, labour) and from voluntary organizations.

On the international level, the UN General Assembly had decided to form an Advisory Committee to draft a programme for the IYDP, and Kenya was appointed as a member of this committee. ${ }^{17}$ Meanwhile, Libya had also proposed a resolution at the Sixth Summit Conference of Heads of State and/or Governments of the Non-Aligned Countries in Havana in 1979, urging members of the Non-Aligned Countries to "give aid and support" to the IYDP and "to work within the United Nations to ensure its success." ${ }^{18}$ On the national level, the preparations in Kenya seem to have slowed down after 1977, which might have been due to the death of President Jomo Kenyatta in 1978 and the election of Daniel arap Moi as the new president. From 1979, however, there was a lot of planning going on, especially when Moi declared that 1980 would be a "National Year of the Disabled," preceding the International Year.

This was also a moment for people with disabilities to weigh in and offer their expertise. Several disabled people's organizations (DPOs), in which people with disabilities organized themselves to demand improvements in social services and access to society, were in existence by that time in Kenya. The Kenya Union of the Blind (KUB) was the oldest one, established in 1960, and they

14 The name would later be changed to International Year of Disabled Persons.

15 Francis K. Muthaura to Mr. Mwashumbe, 26 November 1976, AMP/23/2, Vocational Rehabilitation - General, 1976-1984, Kenya National Archives (KNA), Nairobi.

16 J.M. Tsuma to Mr. Mahinda, 9 and 23 February, 1977, AMP/23/2, Vocational Rehabilitation General, 1976-1984, KNA.

17 A.M. Nderi to Commissioner for Social Services, 15 August 1979, AMP/23/2, Vocational Rehabilitation - General, 1976-1984, KNA. Although they did attend the first meeting of the committee, they are no longer mentioned as members in the second meeting. The reason why they dropped out is unclear.

18 E.K. Okari to Ministry of Housing and Social Services and Commissioner for Social Services, 13 November, 1979, AMP/23/2, Vocational Rehabilitation - General, 1976-1984, KNA. 
wrote to the Commissioner for Social Services to contribute and participate in the programmes for the IYDP. ${ }^{19}$ Similarly, the secretary general of the Kenya Deaf Union Football Club wrote to the Ministry of Housing and Social Services that his organization would like to contribute to the programme of the IYDP by raising funds for different organizations for disabled children. "We being former disabled children would like to raise funds for our young disabled brothers and sisters still in schools and show Kenyans that the disabled too are willing to join them in National activities for development."20 Disabled students from the University of Nairobi wrote a memorandum to their government to call attention to some of the problems they were facing and suggest possible solutions. $^{21}$ The government in turn tried to incorporate the wishes and demands of disabled Kenyans by organizing "grass-root forums" "to enhance the participation of the disabled in national development and their integration in to the society" and to "enhance opportunities for exchange of ideas." 2

In 1980, the national year for disabled persons was marked by several events, involving government, voluntary organizations and D POs. Some of these events focused on publicity and awareness-raising, showcasing the work that the Kenyan government was already undertaking. Most notable in this regard was an exhibition, "to publicize the urgent need for provision of equal opportunities in education and training for all children and adults irrespective of their status or disabilities." ${ }^{23}$ Originally planned as a special education exhibition, aimed at informing the general public of the need for education for children with disabilities and the existing facilities in Kenya, it turned into a broader "1980 National Year for the Handicapped Exhibition." Other activities were more structural, aimed at supporting the design and improvement of policies. A national survey was initiated, to finally obtain reliable numbers on disability within the Kenyan population. ${ }^{24}$ In a presidential fundraising effort in October

19 Philip P.C.S. Onjor to Commissioner for Social Services, 26 September, 1979, AMP/23/2, Vocational Rehabilitation - General, 1976-1984, KNA.

20 Solomon A. Kayia to Ministry of Housing and Social Services, 14 November, 1979, AMP/23/2, Vocational Rehabilitation - General, 1976-1984, KNA.

21 Gitari M.C., Indeche M.O. and Ouma J.H.O. to the Minister for Constitutional and Home Affairs, 8 November 1980, AAT/1/7, International Year for the Disabled, 1977-1981, KNA.

22 "Grass-root - district - provincial forums of the disabled: 'the disabled persons echo'," 21 November, 1981, XH/9/14, International Year of the disabled persons. Grass-root - district provincial forums of the disabled, 1981, KNA.

23 Minutes of the publicity committee meeting, 7 December, 1979, AMP/23/2, Vocational Rehabilitation - General, $1976-1984$, KNA.

24 Idem. 
1980, twenty-one million Kenyan Shillings were collected. ${ }^{25}$ Furthermore, Moi set up a National Fund for the Disabled Persons of Kenya in 1980, to sponsor projects and cover recurrent costs for voluntary organizations or (government) institutions catering for Kenyans with disabilities. ${ }^{26}$

The national year transitioned into the international year in 1981, and initiatives were continued throughout that year. At the end of the IYDP in 1981, a conference was held in Nairobi and from the discussions at this conference a "Plan of Action for the 8os" was drafted. ${ }^{27}$ This document set out the guidelines for the future programme of services for disabled Kenyans. This plan of action was intrinsically linked to the general National Development Plan of 19791983, which focused "its attention on the allevation (sic) of poverty through increased economic growth ..." To reach these goals "all national resources at ... disposal, and especially human resources" had to be "fully mobilized and utilized to the optimum." This meant that the main goal of a plan of action had to be the integration "of all disabled persons in the National Development process." ${ }^{28}$ The main focus of a future programme was therefore the vocational rehabilitation of people with disabilities, providing training and guidance to integrate them into Kenya's labour force. ${ }^{29}$ In the next section, I will show how this focus on rehabilitation could be seen more as representing continuity than a radical break with the past by introducing "global" and unfamiliar concepts.

4 Vocational Rehabilitation in Kenya, 1942-1980

Rather than introducing new concepts to Kenya, the IYDP acted as a stimulus to continue and maybe intensify the programmes that were already in place. In Kenya, these programmes had since their inception focused on vocational rehabilitation. If we trace back the origins of what happened in 1981 to the colonial period, it becomes clear that the IYDP was not a moment of new and

25 International Year of Disabled Persons Secretariat. Commemoration of International Year of Disabled Persons in the Republic of Kenya, 3 February 1981, AMP/23/5, Vocational rehabilitation - general, 1979-1981, KNA.

26 Declaration of trust on the establishment of a National Fund for the Disabled Persons of Kenya, 1980, AMP/5/31, Association for the physically disabled, 1980-1981, KNA.

27 "Kenya's Plan of Action for 1980's. Proposed Programmes of Services for Disabled Persons in 1980's," [1982], box 18, AMP/5/32, Association for the physically disabled, 1981-1984, KNA.

28 Ibid.

29 Ibid. 
"global" approaches, but a moment of reconfirming and publicizing developments that had been going on for about forty years.

As in West Africa, the Second World War was the immediate cause for the British to introduce rehabilitation services to their colonies in East Africa. ${ }^{30}$ In November 1942, on the grounds of the Native Civil Hospital in Nairobi, the colonial government of the Kenya Colony erected an African Rehabilitation Centre. This centre was first and foremost intended for African ex-soldiers injured during service, irrespective of their country of origin. In the centre they received rehabilitation services for their various physical disabilities: physiotherapy, exercise, massages, and even dancing to the "old Charlestone."31 In the beginning, this allegedly "most cheerful and contented group" consisted solely of ex-soldiers, except for one civilian. ${ }^{32}$ The idea was that civilians would also be allowed to access services at the centre, provided there was enough room. In a 1946 pamphlet titled Rehabilitation for the African, an anonymous author called for the expansion of the services provided in the centre, to offer them to civilians, including women and children: "If Rehabilitation is not adopted universally throughout the whole of Africa," he argued, "it will not only be a great loss to the Colonial Medical Services, but a greater loss to the African." ${ }^{33}$

Quite quickly, debates arose within the colonial administration about expanding these kinds of services not only to include civilians with disabilities, but also to include educational provisions. The first efforts in this direction in Kenya came not from the government, but from different missionary and charitable organizations, which set up educational projects for different categories of disabled persons. The Salvation Army, subsidized by the Kenyan government, set up the first experiment. In 1942, Colonel Barrell and his wife started teaching Thomas, a blind man from the Coast district, in an improvised class in

$30 \quad$ Grischow, J.D. "Kwame Nkrumah, Disability, and Rehabilitation in Ghana, 1957-66." The Journal of African History $5^{2}$ (2) (2011), 179-199; Grischow, J.D. "Disability and Rehabilitation in Late Colonial Ghana." Review of Disability Studies: An International Journal 7 (3 \& 4) (2014); Grischow, J.D. "Disability and Work in British West Africa." In The Oxford Handbook of Disability History, eds. M. Rembis, C.J. Kudlick and K. Nielsen (Oxford: Oxford University Press, 2018), 213-28.

31 Report on conference on rehabilitation and artificial limbs by the Surgical Specialist of Sewa Hadji Hospital, 19 July 1944, Ministry of Health, File 1209, Rehabilitation 1941-1946, Tanzania National Archives (TNA), Dar es Salaam.

32 "The Physical rehabilitation of African personnel discharged from the military forces on account of injuries. Notes on the African Rehabilitation Centre at Nairobi," 8 March 1943, Ministry of Health, File 1209, Rehabilitation 1941-1946, TNA.

33 Rehabilitation for the African. An Account of No. 1 General Hospital in the East Africa Command (Dar es Salaam: Government Printer, 1946). 
Nairobi. A few months later, the school expanded as five more students joined. Again, the timing was not a coincidence, as the war effort played an important role in this experiment as well. Colonel Barrell expected that the war would bring about a large number of "war blinded African Soldiers - sturdy fellows who earned their livings or worked on the land before the war and who are now as helpless as babes and no longer able to support their families." 34 Therefore, he envisioned a blind colony a few miles outside of Nairobi, "where the Ex-service blind and civilian blind of the Colony could be gathered ..., taught how to take care of themselves and trained for some vocation." ${ }^{35}$ This last part is important, as it points to a clear focus on vocational training, and thus productivity, educating the blind to enable them to become telephone operators, clerks, teachers, or handicraft workers. The colonel's vision was eventually realized, when in 1946 the Salvation Army opened a School for the Blind in Thika. The model of the Thika school was very influential, as was the inherent paternalism, training "helpless babes" on how to take care of themselves.

The model that both government and other institutions eventually introduced to the British colonies was the same as that which came to be solidified in the Disabled Persons (Employment) Act of 1944, in which full citizenship was linked to the right to participate in the labour market. ${ }^{36}$ This model of "social orthopaedics" was aimed at the rehabilitation of people with disabilities, defining their citizenship in terms of productivity. In the different territories of the Empire, people with disabilities were to be included in the workforce, in order to contribute to the economic rehabilitation and development of the colony. ${ }^{37}$ This mirrored developments in the metropole, where "central government encouraged schemes of rehabilitation as a way of returning disabled people to the work environment, thereby reducing the welfare bill."38 Rehabilitation, thus, was not so much about social welfare as it was about ensuring that the efforts led to employment and that, consequently, disabled people were turned into taxpayers. In the so-called Tomlinson Report, an influential report produced by the Ministry of Labour and National Service, the basic view of disability and its treatment through rehabilitation was set out. A disabled

34 "Training blind Africans. Highly successful Kenya experiment," November 1943, CO 968/139/7, Rehabilitation of blind persons: East Africa, The National Archives, Kew. "Training blind Africans."

36 Borsay, A. Disability and Social Policy in Britain since 1750: A History of Exclusion (New York: Palgrave Macmillan, 2005), 135.

37 Grischow, "Disability and Rehabilitation in Late Colonial Ghana," 43.

38 Anderson, J. "Turned into Taxpayers': Paraplegia, Rehabilitation and Sport at Stoke Mandeville, 1944-56." Journal of Contemporary History 38 (3) (2003): 462. 
person was seen as a "double loss to the community": unable to be productive and a cost in terms of care and treatment. Therefore rehabilitation was crucial, as the report stated that "the restoration of the disabled person to productive employment will be an economic advantage." ${ }^{39}$ This basic view would become the main paradigm in the coming decades, including in Kenya.

At the same time, this was also the underlying rationale for the concept of vocational rehabilitation, and the main international organization promoting this concept was the International Labour Organization (ILO). The ILO had been involved with vocational rehabilitation since after the First World War and entrenched its commitment in the 1955 Vocational Rehabilitation (Disabled) Recommendation (No. 99), which defined the concept as "that part of the continuous and co-ordinated process of rehabilitation which involves the provision of those vocational services, e. g. vocational guidance, vocational training and selective placement, designed to enable a disabled person to secure and retain suitable employment." ${ }^{\prime 0}$ For the ILO, vocational rehabilitation was also about productivity and national development, whereby people with disabilities were seen as unproductive citizens or "former or potential [sic] skilled workers" that had to be made productive again for the sake of economic development. In other words, "the employment of the disabled leads to an increase in over-all production and reduces the number of economically unproductive persons."41

Especially after 1945, technical assistance in so-called "underdeveloped areas" became the second pillar of the ILO's organizational structure, gaining equal status with its standard-setting activities. During the following decade, under Director-General David Morse, the ILO grew into an international development agency. Vocational training - in a broad sense - had been an important aspect of technical assistance programmes since the very beginning. ${ }^{42}$ It is thus not surprising to see that the ILO after issuing the 1955 Recommendation initiated several technical assistance programmes in the field of vocational rehabilitation in Kenya and elsewhere in Africa. ${ }^{43}$ When the newly independent Kenyan government started to develop a national disability policy in the $1960 s$, the ILO was therefore never far away.

\footnotetext{
39 Quoted in Anderson, J. “Turned into Taxpayers," 469.

$40 \quad$ ILO. Vocational Rehabilitation (Disabled) Recommendation (No. 99) (1955).

41 ILO. Basic Principles of Vocational Rehabilitation of the Disabled (Geneva: International Labour Office, 1967), 7 .

42 Maul, "Help Them Move the ILO Way," 387-404.

43 Bregain, G. Pour une histoire transnationale du handicap: Europe et Amériques [A transnational history of disability: Europe and the Americas], (Rennes: Presses Universitaires de Rennes, 2017), 106-107.
} 
After independence in 1963, the Kenyan state was quick to develop a national policy on disability. In May 1964 a Committee for the Care and Rehabilitation of the Disabled was appointed by the Cabinet, under the chairmanship of Minister for Labour and Social Services, Eliud Ngala Mwendwa. In August of the same year the committee published its results in a report. The report consisted of thirty recommendations that would form a guideline for the government to develop a national rehabilitation programme. Rather than presenting a radically new programme, the report built on earlier colonial efforts. The committee stated that one of its objectives was that "the fullest use should be made of existing facilities and that elaborate and expensive plans for development should be eschewed."44 Continuities between colonial and postcolonial policies can be attributed not only to financial constraints but also to the fact that the organizations and people that initiated several programmes and institutions during late colonial times continued to play important roles after independence. The deputy chairman of the committee, for example, was Alexander Mackay, who had been the leading figure of the Kenya branch of the Empire Society for the Blind, which became the Kenya Society for the Blind in 1956. Charitable organizations like this one or the Kenya Society for Deaf Children continued to exert considerable influence as they closely cooperated with the government and were in charge of several schools and institutions. The same is true for missionary societies, like the Salvation Army, which was still in charge of the well-known Thika School for the Blind. It is thus no wonder that the report mentioned that voluntary organizations

would continue to play a most important part in the development of services for the disabled and, in accordance with the principle that the fullest use should be made of existing facilities, we hope that their work will be expanded and developed. ${ }^{45}$

The Committee for the Care and Rehabilitation of the Disabled was unsurprisingly, in line with colonial developments, more focused on rehabilitation than on care. People with disabilities would be turned "from a liability into an asset:" "From being a drain on the country's economy he becomes a wageearner and can play his part - even if only a humble one - in helping to build the nation." 46

\footnotetext{
44 Mwendwa, E.N. Report of the Committee for the Care and Rehabilitation of the Disabled in Kenya (Nairobi: Ministry of Labour and Social Services, 1964), 2.

45 Ibid., 26.

46 Ibid., 2.
} 
These ideas are reminiscent of earlier notions about the link between a healthy and a productive population, the latter being a prerequisite for development. Indeed, the introduction of rehabilitation services under colonial rule and their expansion after independence can be read as complementary to opening up medical services to 'indigenous' populations, something the British had been doing since the 1920s. What one medical expert reporting on sanitary conditions in East Africa wrote in 1914 very much resonates with the language in the Mwendwa Report: "It cannot be emphasized too strongly or too frequently that a healthy native population is the chief asset of East Africa." ${ }^{47}$ Indeed, the concerns raised about disability and the rationale behind the rehabilitation paradigm connect to broader concerns about the need for productive citizens, present since colonial times but still central to policies in the postcolonial developmental state in Africa. In different versions of African socialism, for example, ideas about self-reliance were crucial and individual self-reliance was linked to that of the entire nation (or even the continent as a whole). This was very explicitly and radically present in Nyerere's project of ujamaa in Tanzania from 1967 to 1975 . In this socialist utopia collective hard work was crucial if development was to succeed, as "the productivity of each individual Tanzanian was linked to national prosperity by a chain of selfsufficiency extending through the various political scales of the spatial imaginary at the heart of ujamaa villagization." 48 Although Kenya chose a much more capitalist path than its neighbour, a similar rhetoric was present in the government's vision of an African Socialism, especially in the concept of $h a-$ rambee. In his preface to the famous Sessional Paper no. 10 of 1965, President Kenyatta captures this spirit in his closing sentences: "Let all the people of our country roll up their sleeves in a spirit of self-help to create the true fruits of UHURU. THIS IS WHAT WE MEAN BY HARAMBEE."49

All these ideas about individual productivity linking to the development of the nation as a whole also corresponded entirely with the ILO's vocationalrehabilitation concept of turning "economically unproductive persons" into productive citizens. It is therefore no surprise to find that technical experts from the ILO were also involved in the development of Kenya's national programme. Already in June 1963, about six months prior to Kenya's independence, ILO expert Edgar Marland came to Kenya to carry out a very short

47 Quoted in Hodge, J.M. Triumph, 122.

48 Lal, P. "Self-Reliance and the State: The Multiple Meanings of Development in Early PostColonial Tanzania." Africa, 82 (2) (2012), 214.

49 Kenyatta, J. "Statement by the President." In Sessional Paper No. 10. African Socialism and its Application to Planning in Kenya (Nairobi: Government Printer, 1965), ii. 
survey of about five days. He had done similar surveys in Ceylon, Ethiopia and Pakistan. ${ }^{50}$ In Kenya, he visited a few institutions run by organizations like the Salvation Army, the Kenya Society for the Blind, and the Kenya Society for Deaf Children. He wrote a five-page report of which the main conclusion was that it was necessary to have a central body to coordinate the existing services and that additional government support was needed. Attached to this report was a copy of ILO recommendation no. 99, "in order to assist the Government in preparing a vocational rehabilitation programme."51

After the committee published its report in 1964, ILO assistance continued. Most of the recommendations in the report made their way into Sessional Paper No. 5 of 1968, which laid the ground for future government actions on rehabilitation of people with disabilities, the first of which was the establishment of the Division of Vocational Rehabilitation in the Department of Social Services. ${ }^{52}$ The drafting of that sessional paper and the subsequent creation of a Vocational Rehabilitation Division within the Department of Social Services happened with the close cooperation of another ILO expert, Mr. E.G. Johnson, a Briton who had experience with technical assistance in Uganda. ${ }^{53} \mathrm{He}$ was in Kenya from 1969 to 1972 to assist the government in implementing a "national vocational rehabilitation programme. ${ }^{54}$ He worked within the Department of Social Services, where he also trained a counterpart, Mr. Oisebe, to take over once he left. Despite a few hiccups and small conflicts, there seems to have been an overall appreciation of the work done by Mr. Johnson. In a letter from the office of the Commissioner for Social Services to the permanent secretary of the Ministry of Co-operatives and Social Services, this view is reflected, as

50 See Marland, E. Report to the Government of Ceylon on the Vocational Rehabilitation of the Blind and the Deaf and Other Physically Handicapped Persons (Geneva: International Labour Office, 1960); Marland, E. Report to the Government of Pakistan on the Vocational Rehabilitation of the Disabled (Geneva: International Labour Office, 1961); Marland, E. Report to the Government of Ethiopia on the Vocational Rehabilitation and Employment of Disabled Persons and Related Activities (Geneva: International Labour Office, 1961).

$5^{1}$ Marland, E. Vocational Rehabilitation of the Disabled, August 1963, AE/3/277, Rehabilitation of the Disabled, 1964-1968, KNA.

52 Mwendwa. Report of the Committee for the Care and Rehabilitation of the Disabled in Kenya; Gebrekidan, F.N. "Disability Rights Activism in Kenya, 1959-1964: History from Below." African Studies Review 55 (3) (2012), 115-16.

53 See Johnson, E.G. Report to the Government of Uganda on the Vocational Rehabilitation of the Disabled (Geneva: International Labour Office, 1969).

54 Johnson, E.G. Report to the Government of Kenya on the Development of a National Programme of Vocational Rehabilitation of the Disabled (Geneva: International Labour Office, 1972), 1. 
the author wrote to ask permission "to collect money for a farewell party in his honour" because of "the fact that Mr. Johnson has done a tremendously good work in establishing the Vocational Rehabilitation scheme and in training the staff." 55 This close cooperation with an ILO expert led the then Deputy Principal Vocational Rehabilitation Officer in 1979 to conclude that "by 1970, the programme was in full operation, on I.L.O principles and guid[e]lines but on our local setting. ${ }^{n 6}$

The creation of the vocational-rehabilitation division as the leading government agency in disability services and policies confirmed vocational rehabilitation as the guiding principle. The division was to provide "disabled persons with the opportunity to learn employable skills and take their rightful place in the community to enjoy the benefits of citizenship and contribute their talents towards the social and economic development of the Nation." ${ }^{57}$ All throughout the 1970s, vocational-rehabilitation services expanded and new training centres were built. By the end of the decade, the government was running ten vocational-rehabilitation centres in eight different provinces. On top of that, there were other centres that were run by voluntary organizations that received an annual grant-in-aid from the government, such as the Association for the Physically Disabled of Kenya or the Salvation Army. 58

This historical trajectory brings us back to 1981 , with the International Year of Disabled Persons and the launching of Kenya's Plan of Action for the 1980s that marked the end of that year. In the introduction to that plan, one could read the following rationale:

Effective utilization of human resources calls for increased participation and full integration of all Kenyans in the National Development process. But this can only be fulfilled if the disabled Kenyans, currently estimated at 1.5 million, or $10 \%$ of the total population is integrated in this development process. The exclusion of such a large number of disabled Kenyans from active productive life not only deprives the nation of available resource and productivity but serves only to increase

\footnotetext{
55 Mr. Oisebe to Mr. Kobai, 29 April 1972, File AMP/20/15, Technical Assistance (rehabilitation general), 1971-1981, KNA.

56 Ayodo, T.M.O. “Vocational Rehabilitation in Kenya," AMP/23/2, Vocational Rehabilitation general, 1976-1984, KNA.

57 Department of Social Services. The Vocational Rehabilitation Programme in Kenya, 1980, BF/11/12, The Vocational Rehabilitation Programme in Kenya, 1980, KNA.

58 Ibid.
} 
the dependency ratio which is already high and the concomitant impoverization. ${ }^{59}$

Tracing the longer history of disability policies in Kenya shows how this outcome of the IYDP was not in fact something new or "global." The above words echo the guidelines set out in the report of 1964, which had been deeply influenced by earlier colonial concepts of "social orthopaedics" and by ILO principles. The question now confronts us: what was the historical significance of an international observance like the IYDP in a country like Kenya, and how do we go about analysing it?

It is worth looking at what the authors of the OAU's Continental Plan of Action in 2002 actually meant when they stated that the UN Decade had provided a "global approach." That statement is explained as follows: "the solutions that were offered were general and global - or based on assumptions of availability of economic and technical resources." ${ }^{\prime 0}$ In other words, the solutions on offer were not adapted to the economic realities of African countries. This kind of criticism was not new and had also come from within the UN sphere itself. Already in 1981 then Director General of the wHo Halfdan Mahler took the IYDP as an occasion to evaluate the earlier policies of his organization. His verdict was quite similar to that of the OAU almost twenty years later, stating that "results at least in the third world have been disappointing." He attributed this to "a tendency to apply in developing countries methods and approaches transferred from industrialized nations without adaptation to conditions prevailing in the countries concerned."61 This kind of analysis is, of course, one that we as historians should take seriously and can investigate. Indeed, critical disability scholars have already called for an analysis of how disability knowledge circulates in a postcolonial world. Shaun Grech, for example, urges scholars to investigate how Global North "structures (global North universities and organisations) ... maintain [an] epistemic and material superiority and the exportation/imposition of its 'knowledge', methods ... and practice to an

\footnotetext{
59 "Kenya's Plan of Action for 1980s," 2.

6o African Union, Continental Plan, 5.

61 Mahler, H. "The International Year of Disabled Persons and The World Health Organization." International Rehabilitation Medicine 3 (1) (1981), 1.
} 
undeveloped South space historically (re)constructed ontologically as perpetually deficient." 62

In order to do this, however, we should be careful not to reproduce globallocal dichotomies. In this article, taking a cue from the historiography on development and especially the writings of Joseph Hodge, we have shown how writing longer, deeper and wider histories can help in moving this kind of historical exercise forward. This article therefore demonstrates how this way of approaching the International Year of Disabled Persons can make several contributions. First of all, it illustrates how knowledge about disability (and knowledge in general) circulates transnationally, in both colonial and postcolonial contexts. It also shows what kinds of roles international organizations, like the ILO, played in this process. This leads to the second point, which is that this kind of history also sheds further light on the history of international organizations. It helps us understand the nature of international observances (decades, years, days), in this case not as moments of renewal or radical change, but as a heightened commitment to already on-going developments, where national governments and populations also have a huge role to play. That in turn leads to a better understanding of how international organizations work, not on an abstract international level, but through technical experts, working together with national actors on the ground. So what can be learned from a longer, deeper and wider history of the IYDP in Kenya?

The longer perspective is vital in assessing what was new and what was not. If we want to take seriously the calls by scholars to consider the "coloniality" of how disability knowledge circulated, we need to look at what happened during colonialism. ${ }^{63}$ Doing this for Kenya has shown how during late colonialism a foundation was laid for what would become a national policy centred on vocational rehabilitation. It was during the 1940 s and 1950s that disability increasingly became defined as a problem of (un)productivity, to which rehabilitation formed the most important solution. This helps us understand how the interventions by ILO experts from the 196os onwards and the IYDP in 1981 were building on colonial foundations. This means that when observers were criticizing interventions for being too "global" and not adapted to "local"

62 Grech, S. "Decolonising Eurocentric Disability Studies: Why Colonialism Matters in the Disability and Global South Debate." Social Identities 21 (1) (2015), 17.

63 See for example Meekosha, H. "Decolonising Disability: Thinking and Acting Globally." Disability \& Society 26 (6) (2011), 667-82; Grech, S., and K. Soldatic. "Disability and Colonialism: (Dis)Encounters and Anxious Intersectionalities." Social Identities 21 (1) (2015), $1-5$. 
circumstances, they were pointing to problems that had their origins in late colonialism. This does not contradict a postcolonial approach to, for example, the ILO, but rather helps to deepen such an approach. By analysing how the ILO actually worked and how its interventions were rooted in the imperial project, it allows for a much more precise critique of how its programmes impacted societies in the Global South.

Writing a deeper history, which according to Hodge means "examining more closely how ... ideas and policies play out on the ground and in practice in specific contexts" with all possible "contradictions, nuances, and debates," helps us to further unpack notions of globality and locality. ${ }^{64}$ These kinds of histories are in line with the "heuristic displacement" Sandrine Kott talks about, moving away from the abstract international level to, for example, the actual work of technical agencies. ${ }^{65}$ It is also more anthropological, not focusing on the "grand plans" Li refers to but rather the "social life" of interventions as Mosse would have it. ${ }^{66}$ For the IYDP, such a "grand plan" would be the World Programme of Action, drafted by the Advisory Committee for the International Year of Disabled Persons and the Centre for Social Development and Humanitarian Affairs. This document, which was to be implemented during the International Decade, would serve as "a declaration of principles but also a blueprint for action." 67 The objectives of the World Programme of Action were to promote prevention, rehabilitation and equalization of opportunities for people with disabilities. "These concepts," the authors proclaimed, "should apply with the same scope and with the same urgency to all countries regardless of their level of development." 68

Such international, universalistic "world" plans and rules show how at the UN level there was certainly an ambition to offer a "global approach" to the problems of disability. Yet, in turning the focus from international policy towards what was "happening on the ground" in Kenya, another image emerges. This is a more bottom-up image. At the national level, the Kenyan government used the IYDP to reinvigorate, intensify and publicize its vocationalrehabilitation programme. The Vocational Rehabilitation Division could use the IYDP to emphasize Kenya's "position of prominence in its concern for its

\footnotetext{
64 Hodge, "Writing the History of Development," 137.

65 Kott, "International Organizations," 447.

66 Li, The Will to Improve, 6; Mosse, Cultivating Development, 6.

67 UN, "World Programme of Action Concerning Disabled Persons: Report of the SecretaryGeneral, Addendum," Pub. L. No. A/37/351/Add.1, 1982 (1982), 6, 8. 
disabled population." ${ }^{\prime 9}$ Declaring 1980 a national year was another important step in boosting Kenya's image of progressiveness in disability policies. "We have proved to the world that we are ahead of the UN in this sphere," President Moi proudly announced in $1981 .{ }^{70}$ The examples of DPOs and people with disabilities wanting to contribute to the national and international years further illustrates how the IYDP could be appropriated by different actors on national or local levels.

Lastly, this article also provided a wider history, taking into account a range of actors much broader than "the UN" or its specialized agencies. This helps not only to deconstruct what constituted a UN observance, but also to think through the question what we are talking about when we discuss the UN or its different agencies. The IYDP may have been a UN observance, but for Kenyans, it was much more of a national effort. This was led by the Vocational Rehabilitation Division at the Department of Social Services, but also involved people with disabilities themselves, often organized through their own DPos. The example of the secretary general of the Kenya Deaf Union Football Club writing to the Ministry of Housing and Social Services to contribute to fundraising is a good illustration of this. Moreover, the heightened national and international attention created by the IYDP could also be seized by deaf people in Kenya to further push for their rights. In the years following 1981, deaf Kenyans further organized themselves politically - in close cooperation with a team from the Swedish Association of the Deaf - and made demands beyond the vocationalrehabilitation policy of their government, most notably the development and recognition of a Kenyan Sign Language. ${ }^{71}$

Of course, this national history was in turn very much transnationally entangled, and one actor that definitely had an important role was the ILO. However, rather than talking about the ILO, it would be more accurate to look at the specific technical experts who went to Kenya and worked within the Department for Social Services. This, combined with the writing of a longer history, also shows how these experts built on colonial precedents. Gildas Bregain has already pointed towards the "continuities between the actions of

69 “Kenya's Plan of Action for 1980's. Proposed Programmes of Services for Disabled Persons in 1980s," [1982], box 18, AMP/5/32, Association for the physically disabled, 1981-1984, KNA.

$70 \quad$ KNA, "Act Now on the Disabled - Moi," Daily Nation, 25 March, 1981.

71 See Okombo, D.O., and Akach, P. "Language Convergence and Wave Phenomena in the Growth of a National Sign Language in Kenya." International Journal of the Sociology of Language 125 (1) (1997), 131-44; Morgan, H.E. et al. "Kenyan Sign Language." In Sign Languages of the World: A Comparative Handbook, eds. Jepsen, J.B. et al. (Berlin: De Gruyter, 2015), 529-52. 
British imperial organisations ... and those developed by the UN, the ILO and UNESCO" in the field of disability policies. ${ }^{72}$ This is also true for the Kenyan case, as the first ILO experts before and after independence could build on the framework laid out by the colonial government and organizations like the Salvation Army. The institutions that they created and the ideas about disability and productivity that they launched formed the ideal basis on which the ILO experts could build their vocational-rehabilitation policies. These experts in turn built on their own experiences in other Global South countries and, more importantly, continued to carry out similar projects in other countries, thereby contributing to a transnational circulation of expertise that was grounded in experiential, "on the ground" knowledge rather than universal "grand schemes."

\section{Conclusion}

When at the turn of the millennium the OAU evaluated the events that had followed the IYDP since 1981 and concluded that they were too global and general, they proposed a more local approach, adapted to the specific circumstances of the different African countries. This article has shown that such a "local approach" was illusory by the 1980 s, as by that time the paradigm of vocational rehabilitation was part and parcel of the political thinking about disability, and this concept was very much transnationally constituted as a longer history since the Second World War illustrates. In the same vein, the IYDP and the consecutive International Decade were hardly global. We must therefore, as historians, be cautious not to reiterate such political claims about global-local dichotomies. "That global should be contrasted with local," Frederick Cooper reminds us, "only underscores the inadequacy of current analytical tools to analyse anything in between." ${ }^{\prime 3}$ If we want to be able to say anything meaningful about international observances, or indeed about the UN or international

72 Bregain, G. Pour une histoire transnationale du handicap: Europe et Amériques [A transnational history of disability: Europe and the Americas], (Rennes: Presses Universitaires de Rennes, 2017), 131. The imperial roots that Bregain points to for disability policies at the UN level are part of a wider story of the imperial origins of the UN system, as noted for example in Mazower, M. No Enchanted Palace: The End of Empire and the Ideological Origins of the United Nations (Princeton, N.J.: Princeton University Press, 2009), or more specifically for the ILO in the first part of Fiti Sinclair, G. To Reform the World: International Organizations and the Making of Modern States (Oxford: Oxford University Press, 2017).

73 Cooper, F. "What Is the Concept of Globalization Good for? An African Historian's Perspective." African Affairs 100 (399) (2001), 192. 
organizations in general, we will need those analytical tools to look at the spaces "in between" the global and the local.

This article has attempted to look at the diplomacy that took place within those spaces. David Webster has pointed to how in the 1950s technical assistance at the UN came to the fore as a "new form of diplomacy." According to its proponents, " $[\mathrm{m}]$ ore than a simple process of skills transfer, it was a diplomatic act, one that was even more complex than traditional diplomacy."74 This resonates with the tennets of New Diplomatic History, with its insistence on acknowledging the role of individuals and non-governmental institutions as diplomatic actors. ${ }^{75}$ It also resonates with the main focus of this special issue on the diplomacy of UN observances. In the introduction to this issue, Paul van Trigt writes that " $[t]$ he origins and planning of the observances involved a range of state and non-state actors that illustrate the complexities of the diplomatic processes involved." ${ }^{\prime 6}$ The focus of this article is exactly on the diplomatic processes involving those different actors, both during the IYDP and in the longer history of its "origins." It shows how different actors - civil servants, state officials, international technical assistants, missionaries, people with disabilities - all supported interventions on disability in the name of development. That development, as Eva-Maria Muschik points out, "cannot be understood as a neo-colonial imposition or a triumph of international understanding," but "as a negotiated process ... which is mediated and shaped by international civil servants." ${ }^{17}$ The diplomacy of UN observances and their origins appear thus not as a global imposition nor as a local reaction, but as a transnationally negotiated process.

By contextualizing these observances within longer, wider and deeper histories, and doing this from the perspective of those places where they were being observed, a more nuanced image emerges of how knowledge circulates, while at the same time allowing for a more precise critical analysis of how this circulation takes place within uneven power relations. In that respect, this article is more of a programmatic text, as it reveals only the tip of the iceberg of what a more anthropological approach to the history of international

74 Webster, D. "Development advisors in a time of Cold War and decolonization: The United Nations Technical Assistance Administration, 1950-59." Journal of Global History 6 (2011), 250.

75 See for example Scott-Smith, G. (2014), "Introduction: Private Diplomacy, Making the Citizen Visible." New Global Studies 8 (1) (2014), 1-7.

76 See the introduction to this special issue.

77 Muschik, E-M. "Managing the world: The United Nations, decolonization, and the strange triumph of state sovereignty in the 1950s and 1960s." Journal of Global History 13 (2018), 124. 
organisations could bring to the table. We need much more thorough investigations of how international organizations - or more accurately, international experts - worked on the ground; how they did so in co-operation or conflict with a whole range of other national and transnational actors; how knowledge created on the ground flowed back to the international level and became part of universalizing ideas; how international interventions were experienced and often appropriated by those for whom they were intended; and how, for the Global South, these histories are often part of longer histories tracing back to colonialism. Such longer, deeper and wider histories are needed to historically disentangle the workings of international organizations, and to write often overlooked groups such as Global South actors or people with disabilities into these histories. 